Click www.researchjournal.co.in/online/subdetail.html to purchase.

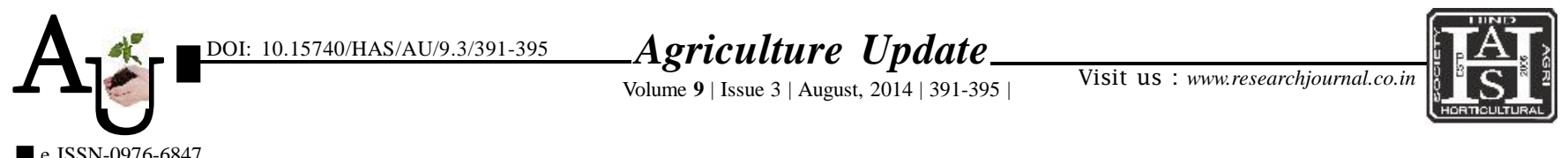

Research Article

\title{
A study on knowledge and adoption of dairy farmers about improved dairy management practices
}

\author{
K.N. MALI, R.B. BELLI AND S.S. GULEDAGUDDA
}

Article Chronicle: Summary : The study was conducted in Belgaum district of Karnataka during year 2012-13. Seventy two Received :

25.11.2013;

Revised :

29.06.2014;

Accepted :

11.07.2014

dairy farmers were selected by proportionate random sampling. The findings of the study revealed that, 37.50 per cent of the dairy farmers had medium knowledge level and 65.28 per cent of the dairy farmers had medium adoption level. Cent per cent of dairy farmers possessed complete knowledge about breeds of cow and buffalo, right time of artificial insemination, pregnancy test, period of insemination after normal calving and selection of breeds. Regarding health care management, majority of dairy farmers $(94.44 \%)$ had complete knowledge about major diseases of dairy animals and symptoms of foot and mouth disease. The majority of dairy farmers $(87.50 \%)$ regularly fed colostrums to newly born calf within half an hour of its birth and more than half $(66.67 \%)$ of dairy farmers practiced pregnancy diagnosis regularly.

How to cite this article : Mali, K.N., Belli, R.B. and Guledagudda, S.S. (2014). A study on knowledge and adoption of dairy farmers about improved dairy management practices. Agric. Update, 9(3): 391-395.

\author{
KeY Words : \\ Knowledge, \\ Adoption, \\ Dairy farmers, \\ Dairy management \\ practices
}

Author for correspondence :

\section{K.N. MALI}

Department of Agricultural Extension Education, College of Agriculture, University of Agricultural Sciences, Dharwad (KARANATAKA) INDIA

Email:kashi4415@ gmail.com

See end of the article for authors' affiliations 